\title{
PENERAPAN MODEL PEMBELAJARAN LANGSUNG (DIRECT LEARNING) PADA KONSEP STRUKTUR ATOM UNTUK MENINGKATKAN HASIL BELAJAR SISWA KELAS X MAN 1 AMBON
}

\author{
Nur Gaib Karepesina \\ Departement of Chemistry-FKIP, Pattimura University Ambon \\ nur karepesina@yahoo.com
}

\begin{abstract}
The direct learning model is one of the learning models of learning models that emphasizes mastery of concepts and / or behavioral changes by prioritizing a deductive approach. The direct learning model is used in the concept of atomic structure to see whether its application can improve the mastery of student learning outcomes in class X MAN 1 Ambon. The study was conducted in October - November 2015, using descriptive research type. The results showed that student learning outcomes reached $45.8 \%$ and were categorized sufficient at the first meeting and $100 \%$ at the second meeting with very good categories. In addition, affective and psychomotor abilities of students also experienced a significant increase. Thus, the application of the direct learning model is stated to be able to improve student learning outcomes.
\end{abstract}

Keywords: Cooperative Learning Model NHT, learning results, Atomic structure

\begin{abstract}
ABSTRAK
Model pembelajaran langsung adalah salah satu model pembelajaran model pembelajaran yang menekankan pada penguasaan konsep dan/atau perubahan perilaku dengan mengutamakan pendekatan deduktif. Model pembelajaran langsung digunakan pada konsep struktur atom untuk melihat apakah penerapannya dapat meningkatkan penguasaan hasil belajar siswa kelas X MAN 1 Ambon. Penelitian dilakukan pada bulan Oktober - November 2015, dengan menggunakan tipe penelitian deskriptif. Hasil penelitian menunjukan bahwa hasil belajar siswa mencapai $45,8 \%$ dan dikategorikan cukup pada pertemuan I dan $100 \%$ pada pertemuan II dengan kategori sangat baik. Selain itu, kemampuan afektif dan psikomotor siswa juga mengalami peningkatan yang signifikan. Dengan demikian, penerapan model pembelajaran langsung dinyatakan dapat meningkatkan hasil belajar siswa.
\end{abstract}

Kata kunci: Model Pembelajaran Langsung, Hasil Belajar, Struktur Atom.

\section{PENDAHULUAN}

Pendidikan berperan penting untuk menjamin kelangsungan hidup suatu bangsa dan negara, karena pendidikan merupakan sarana utama untuk meningkatkan dan mengembangkan kualitas sumber daya manusia. Dimana upaya peningkatan kualitas pendidikan juga dapat dilakukan melalui perbaikan kurikulum (Oemar Hamali, 2010 : 41). Bentuk perbaikan kurikulum yang dilakukan pemerintah adalah melalui Penerapan Kurikulum Tingkat Satuan Pendidikan (KTSP). KTSP bertujuan untuk membentuk dan meningkatkan kreatifitas pembelajaran, serta meningkatkan kualitas pembelajaran di sekolah. Salah satu upaya perbaikan kurikulum dan peningkatan kualitas pembelajaran adalah melalui pembelajaran aktif, dimana siswa dituntut berpartisipasi aktif selama proses pembelajaran.

Guru sebagai komponen penting dari tenaga kependidikan, memiliki tugas untuk melaksanakan proses pembelajaran (Weno, 2009). Dalam pelaksanaannya, diperlukan model pembelajaran yang sesuai dan mampu membangkitkan motivasi siswa untuk belajar. Salah satu model pembelajaran yang dapat membantu siswa dalam memahami materi kimia khusunya materi struktur atom adalah model pembelajaran langsung. Sehingga diperlukan peran aktif guru untuk membantu siswa dalam mempelajari materi yang di sajikan. Model ini menuntut siswa untuk memperhatikan secara serius 
terhadap materi yang di ajarkan, sehingga ketika ada umpan balik dari guru kepada siswa diharapkan siswa dapat memahami dengan baik materi yang disajikan.

Model pembelajaran langsung merupakan salah satu model pembelajaran yang dapat digunakan guru untuk meningkatkan keterampilan proses dan kemampuan memusatkan perhatian serta memotivasi siswa dalam belajar. Berdasarkan hasil pengamatan dan penilaian awal selama obeservasi , pencapaian hasil belajar kimia termasuk pada materi struktur atom masih sangat rendah. Nilai rata-rata kelas X pada semester ganjil tahun pelajaran 2015/2016 belum mencapai Kriteria Ketuntasan Minimal (KKM) yang di tetapkan. Ada beberapa faktor yang menyebabkan sehingga hasil belajar siswa rendah, diantaranya materi yang diberikan bersifat teoritis sehingga siswa sulit memahami secara kompherensif materi yang di sajikan. Hasil belajar siswa juga rendah karena siswa diberikan tugas untuk mempelajari sendiri tentang materi yang akan diajarkan, padahal materi tersebut tergolong sulit dipahami oleh siswa dan membutuhkan bimbingan serta penjelasan secara rinci dari guru.

\section{METODE PENELITIAN}

\section{Jenis Penelitian}

Jenis penelitian yang digunakan adalah penelitaian deskriptif kuantitatif yang bertujuan menggambarkan hasil belajar peserta didik kelas X MAN 1 Ambon pada materi struktur atom dengan menggunakan model pembelajaran Direct instruction (DI) dan dianalisis secara kualitatif dan kuantitatif. Rancangan penelitian menggunakan One Group Pre-tets Post-test Design, dengan rumus sebagai berikut :

\section{$\mathbf{O}_{1} \quad \mathbf{X}$}

(Arikunto, 2006: 85)

\section{Subjek Penelitian}

Yang menjadi subjek dalam penelitian ini adalah siswa kelas X MAN 1 Ambon, tahun ajaran 2015/2016 yang berjumlah 24 siswa.

\section{Variabel Penelitian}

Variabel yang digunakan dalam penelitian ini adalah variabel bebas yaitu penerapan model pembelajaran langsung atau direct instruction (DI) dan variabel terikat yaitu Hasil belajar siswa pada materi struktur atom.

\section{Instrumen Penelitian}

Instrumen yang digunakan dalam penelitian ini adalah :

a. Instrumen tes, berupa tes awal (pre-test) dan tes akhir (post-test) dalam bentuk PG dan Essay.

b. Instrumen non tes, berupa lembar pengamatan afektif, lembar pengamatan psikomotor, lembar kerja.

\section{Teknik Pengumpulan Data}

a. Teknik Tes

Tes diberikan pada awal dan akhir pembelajaran yang bertujuan untuk mengetahui ketuntasan dan tingkat pemahaman siswa terhadap materi pelajaran.

b. Teknik non tes berupa:

Observasi dan Lembar kerja siswa (LKS) 


\section{Teknik Analisa Data}

Data dari hasil penelitian akan diolah dengan menggunakan analisis data kuantitatif. Data yang terkumpul berupa angka yang terdiri dari skor nilai tes, dianalisis dengan menggunakan statistik dekriptif.

1. Hasil belajar Kognitif Produk dapat diperoleh dengan menggunakan rumus :

$$
\text { Nilai }=\frac{\text { jumlah skor siswa yang diperoleh }}{\text { total skor }} \times 100
$$

2. Lembar penilaian afektif dan psikomotor digunakan penskoran sebagai berikut :

$$
\text { skor pencapaian }=\frac{\text { jumlah skor yang diperoleh }}{\text { jumlah skor maksimum }} \times 100
$$

(Sudijono, $2005: 318$ )

Kemudian dari hasil belajar kognitif produk, dikonversikan dengan menggunakan tabel pedomana acuan patokan (PAP) dan kualifikasinya. Dapat dilihat pada tabel 1. berikut :

Tabel 1. Tingkat pengusaan kompetensi dan kualifikasi

\begin{tabular}{cc}
\hline $\begin{array}{c}\text { Tingkat Penguasaan } \\
\text { Kompetensi }\end{array}$ & Kualifikasi \\
$85-100$ & Sangat baik \\
$76-84$ & Baik \\
$68-75$ & Cukup \\
$<68$ & Gagal \\
\hline
\end{tabular}

Tes awal dan tes akhir siswa dianalisis untuk mendapatkan skor peningkatan $N$-gain. Skor peningkatan $N$-gain dapat dihitung dengan rumus :

$$
N-\text { gain }=\frac{\text { skor tes akhir }- \text { skor tes awal }}{\text { skor maksimum }- \text { skor tes awal }}
$$

\section{HASIL PENELITIAN}

Berdasarkan hasil penelitian yang dilakukan menggunakan model pembelajaran kooperatif tipe Direct instruction (DI), terhadap siswa kelas X MAN 1 Ambon, maka berikut ini akan diuraikan tentang hasil belajar siswa.

\section{Pertemuan 1. Hasil Penilaian Kognitif}

Tabel 2. Daftar Nilai Tes Siswa Kelas X MAN 1 Ambon

\begin{tabular}{|c|c|c|c|c|c|c|c|c|}
\hline \multirow{2}{*}{ Kelompok } & \multirow{2}{*}{ Nilai } & \multicolumn{3}{|c|}{ Tes Awal } & \multirow{3}{*}{ Tes Akhir } \\
\cline { 3 - 5 } \cline { 7 - 9 } & & Frekuensi & $\begin{array}{c}\text { Persentase } \\
(\%)\end{array}$ & Ket & Nilai & Frekuensi & $\begin{array}{c}\text { Persentase } \\
(\%)\end{array}$ & Ket \\
\hline \multirow{3}{*}{ I } & $\geq 70$ & 0 & 0 & Tuntas & $\geq 70$ & 2 & 8,3 & Tuntas \\
\cline { 3 - 8 } & $<70$ & 6 & 25 & $\begin{array}{c}\text { Belum } \\
\text { Tuntas }\end{array}$ & $<70$ & 4 & 16,7 & $\begin{array}{c}\text { Belum } \\
\text { Tuntas }\end{array}$ \\
\hline II & $\geq 70$ & 0 & 0 & Tuntas & $\geq 70$ & 3 & 12,5 & Tuntas \\
\hline
\end{tabular}




\begin{tabular}{|c|c|c|c|c|c|c|c|c|}
\hline & $<70$ & 6 & 25 & $\begin{array}{c}\text { Belum } \\
\text { Tuntas }\end{array}$ & $<70$ & 3 & 12,5 & $\begin{array}{c}\text { Belum } \\
\text { Tuntas }\end{array}$ \\
\hline \multirow{3}{*}{ III } & $\geq 70$ & 0 & 0 & Tuntas & $\geq 70$ & 3 & 12,5 & Tuntas \\
\cline { 2 - 8 } & $<70$ & 6 & 25 & $\begin{array}{c}\text { Belum } \\
\text { Tuntas }\end{array}$ & $<70$ & 3 & 12,5 & $\begin{array}{c}\text { Belum } \\
\text { Tuntas }\end{array}$ \\
\hline \multirow{3}{*}{ IV } & $\geq 70$ & 0 & 0 & Tuntas & $\geq 70$ & 3 & 12,5 & Tuntas \\
\cline { 2 - 8 } & $<70$ & 6 & 25 & $\begin{array}{l}\text { Belum } \\
\text { Tuntas }\end{array}$ & $<70$ & 3 & 12,5 & $\begin{array}{c}\text { Belum } \\
\text { Tuntas }\end{array}$ \\
\hline \multicolumn{2}{|c|}{ Jumlah } & 24 & 100 & \multicolumn{2}{|c|}{ Jumlah } & 24 & 100 & \\
\hline
\end{tabular}

Dari tabel diatas pada hasil tes awal, kelompok I yang beranggotakan 6 siswa, seluruhnya tidak memenuhi kriteria ketuntasan (25\%). Pada kelompok II, III dan IV juga masing-masing terdiri dari 6 siswa $(25 \%)$ dalam kelompoknya belum mencapai ketuntasan. Untuk tes akhir, terjadi perubahan pada masing-masing kelompok meskipun tidak signifikan. Pada kelompok I, hanya 2 siswa $(8,3 \%)$ yang mencapai kriteria ketuntasan, dan 4 orang siswa lainnya belum mencapai ketuntasan $(16,7 \%)$. Jumlah siswa yang mendapat ketuntasan di kelompok II sebanyak 3 siswa $(12,5 \%)$ dan 3 siswa lainnya $(12,5 \%)$ belum mengalami ketuntasan. Pada kelompok III, terdapat 3 siswa yang mencapai ketuntasan (12,5\%) dan yang tidak mencapai ketuntasan sebanyak 3 siswa $(12,5 \%)$. Sedangkan pada kelompok IV terdapat 3 siswa yang belum mencapai ketuntasan $(12,5 \%)$ dan yang telah mencapai ketuntasan 3 siswa (12,5\%). Dengan demikian terdapat 13 siswa yang belum mencapai ketuntasan belajar dengan persentase $54,2 \%$ dan yang mencapai ketuntasan sebanyak 11 siswa dengan persentase $45,8 \%$. Perbandingan hasil tes awal dan tes akhir dapat digambarkan pada grafik 1. berikut :

Grafik 1. Hasil Tes SiswaKelas X MAN 1 Ambon

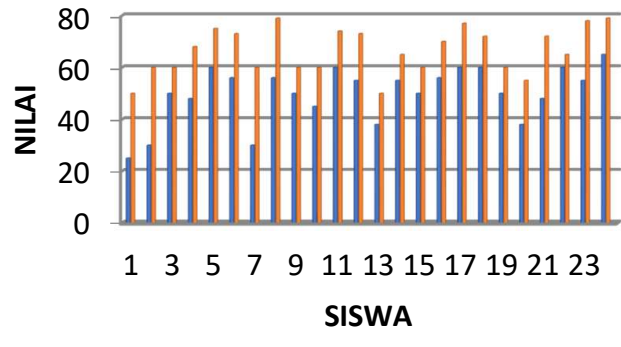

\section{1) Hasil Penilaian Afektif}

Hasil Penilaian Indikator Setiap Kelompok

Hasil penilaian afektif berdasarkan pengamatan untuk masing-masing kelompok dari seluruh indikator adalah sebagai berikut:

Tabel 3. Hasil Penilaian Afektif Siswa Kelas X MAN 1 Ambon

\begin{tabular}{|c|c|c|c|c|c|c|c|c|c|}
\hline \multirow{3}{*}{ Interval } & \multicolumn{8}{|c|}{ Kelompok } & \multirow[t]{3}{*}{ Klasifikas } \\
\hline & \multicolumn{2}{|r|}{ I } & \multicolumn{2}{|r|}{ II } & \multicolumn{2}{|r|}{ III } & \multicolumn{2}{|r|}{ IV } & \\
\hline & Frek. & $\begin{array}{c}\text { Persentasi } \\
(\%)\end{array}$ & Frek. & $\begin{array}{c}\text { Persentase } \\
(\%)\end{array}$ & Frek. & $\begin{array}{c}\text { Persentase } \\
(\%)\end{array}$ & Frek. & $\begin{array}{c}\text { Persentase } \\
(\%)\end{array}$ & \\
\hline $85-100$ & 0 & 0 & 0 & 0 & 0 & 0 & 0 & 0 & $\begin{array}{c}\text { Sangat } \\
\text { Baik }\end{array}$ \\
\hline $70-84$ & 1 & 4,2 & 3 & 12,5 & 2 & 8,3 & 3 & 12,5 & Baik \\
\hline
\end{tabular}




\begin{tabular}{|c|c|c|c|c|c|c|c|c|c|}
\hline $60-69$ & 5 & 20,8 & 2 & 8,3 & 4 & 16,7 & 2 & 8,3 & Cukup \\
\hline $40-59$ & 0 & 0 & 1 & 4,2 & 0 & 0 & 1 & 4,2 & Kurang \\
\hline$<39$ & 0 & 0 & 0 & 0 & 0 & 0 & 0 & 0 & Tidak Baik \\
\hline
\end{tabular}

Dari tabel 3. di atas terlihat bahwa tidak ada kelompok yang menempati interval 85-100 dengan klasifikasi sangat baik. Pada klasifikasi baik dengan interval 70-84 kelompok I memiliki frekuensi 1 siswa dengan persentase $4,2 \%$, kelompok II dan kelompok IV memiliki persentase yang sama yaitu 12,5\% (3 siswa) sedangkan kelompok III dengan frekuensi pada klasifikasi ini sebanyak 2 siswa dengan persentase 8,3\%. Di interval 60-69 dengan klasifikasi cukup kelompok I memiliki frekuensi 5 siswa $(20,8 \%)$, kelompok II dan kelompok IV memiliki frekuensi yang sama yaitu 2 siswa dengan persentase $8,3 \%$ dan kelompok 3 memiliki persentase 16,7\% (4 siswa). Klasifikasi kurang dengan interval 40-59 oleh kelompok I dan kelompok III tidak ada sama sekali, kelompok II dan kelompok IV memiliki persentase yang sama 4,2\% (1 siswa). Pada interval 39 ke bawah dengan klasifikasi kurang tidak ada sama sekali. Dengan demikian skor tertinggi untuk seluruh kelompok adalah pada interval 60-69 (klasifikasi cukup) dengan total persentase 54,1\%, diikuti oleh interval 70-84 dengan klasifikasi baik dengan total persentase $37,5 \%$ dan yang paling terakhir adalah interval 40-59 dengan klasifikasi kurang dengan total persentase $8,4 \%$.

Grafik 2. Hasil Penilaian Afektif Seluruh Indikator Pada Siswa Kelas X MAN 1 Ambon

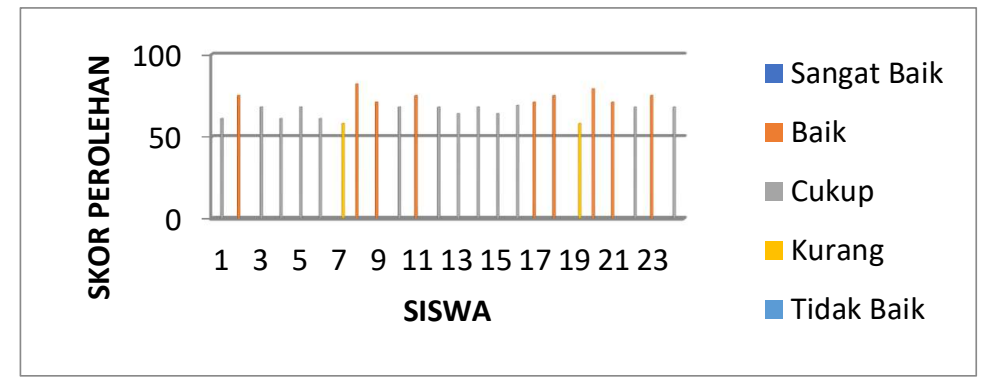

\section{2) Hasil Penilaian Psikomotor}

Hasil Penilaian Seluruh Indikator untuk Setiap Kelompok

Hasil penilaian psikomotor berdasarkan pengamatan masing-masing kelompok dari seluruh indikator adalah sebagai berikut :

Tabel 4. Hasil Penilaian Psikomotor Siswa Kelas X MAN 1 Ambon

\begin{tabular}{|c|c|c|c|c|c|c|c|c|c|}
\hline \multirow{3}{*}{ Interval } & \multicolumn{8}{|c|}{ Kelompok } & \multirow[t]{3}{*}{ Klasifikasi } \\
\hline & \multicolumn{2}{|r|}{1} & \multicolumn{2}{|r|}{ II } & \multicolumn{2}{|r|}{ III } & \multicolumn{2}{|r|}{ IV } & \\
\hline & Frek. & $\begin{array}{c}\text { Persentase } \\
\text { (\%) }\end{array}$ & Frek. & $\begin{array}{c}\text { Persentase } \\
\text { (\%) }\end{array}$ & Frek. & $\begin{array}{c}\text { Persentase } \\
\text { (\%) }\end{array}$ & Frek. & $\begin{array}{c}\text { Persentase } \\
\text { (\%) }\end{array}$ & \\
\hline $85-100$ & 0 & 0 & 0 & 0 & 0 & 0 & 0 & 0 & $\begin{array}{l}\text { Sangat } \\
\text { Baik }\end{array}$ \\
\hline $70-84$ & 1 & 4,2 & 1 & 4,2 & 1 & 4,2 & 1 & 4,2 & Baik \\
\hline $60-69$ & 2 & 8,3 & 2 & 8,3 & 1 & 4,2 & 1 & 4,2 & Cukup \\
\hline
\end{tabular}




\begin{tabular}{|c|c|c|c|c|c|c|c|c|c|}
\hline $40-59$ & 3 & 12,5 & 3 & 12,5 & 3 & 12,5 & 2 & 8,3 & Kurang \\
\hline$<39$ & 0 & 0 & 0 & 0 & 1 & 4,2 & 2 & 8,3 & Tidak Baik \\
\hline
\end{tabular}

Penilaian psikomotor untuk seluruh indikator oleh masing-masing kelompok berdasarkan tabel 4. diatas, menunjukan tidak ada kelompok yang berada pada interval 85-100 dengan klasifikasi nilai sangat baik. Pada interval 70-84 dengan klasifikasi baik seluruh kelompok (kelompok I-IV) memiliki masing-masing jumlah frekuensi 1 siswa (4,2\%). Di interval 60-69 (klasifikasi cukup) kelompok I dan kelompok II terdapat 2 orang siswa dengan persentase 8,3\% dan kelompok 3 mempunyai persentase 4,2\% (1 siswa) dan kelompok IV tidak ada. Kemudian untuk interval 40-59 dengan klasifikasi nilai kurang seluruh kelompok masing-masing terdapat 3 orang siswa dengan persentase $12,5 \%$. Pada interval yang terakhir yaitu pada klasifikasi tidak baik yaitu interval $>39$, kelompok I dan II tidak ada, kelompok III memiliki persentase 4,2\% (1 siswa) dan kelompok IV 2 orang siswa dengan persentase $8,3 \%$.

Dengan demikian interval 40-59 dengan klasifikasi nilai kurang memiliki persentase tertinggi yakni 50\%, disusul interval 60-69 dengan klasifikasi nilai cukup dengan persentase 20,8\%, klasifikasi baik memiliki persentase $16,8 \%$ dan yang paling terakhir adalah interval 39 kebawah dengan persentase $12,5 \%$.

Grafik 3. Hasil Penilaian Psikomotor Siswa Kelas X MAN 1 Ambon

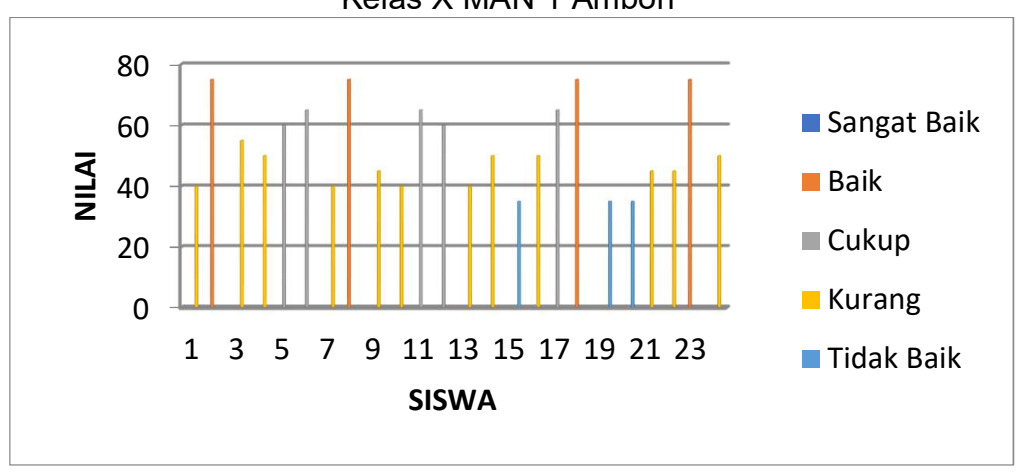

\section{Pertemuan II}

Pada pertemuan ini disajikan pula deskripsi hasil-hasil penelitian tentang penilaian kognitif, penilaian afektif penilaian psikomotor dan penilaian kemampuan peneliti.

\section{1) Hasil Penilaian Kognitif}

Hasil penilaian kognitif dapat dilihat pada tabel 5. di bawah ini :

Tabel 5. Daftar Nilai Tes Siswa Kelas X MAN 1 Ambon

\begin{tabular}{|c|c|c|c|c|c|c|c|c|}
\hline \multirow[b]{2}{*}{ Kelompok } & \multirow[b]{2}{*}{ Nilai } & \multicolumn{3}{|c|}{ Tes Awal } & \multirow[b]{2}{*}{ Nilai } & \multicolumn{3}{|c|}{ Tes Akhir } \\
\hline & & Frekuensi & $\begin{array}{c}\text { Persentase } \\
(\%)\end{array}$ & Ket & & Frekuensi & $\begin{array}{c}\text { Persentase } \\
(\%)\end{array}$ & Ket \\
\hline \multirow[b]{2}{*}{ I } & $\geq 70$ & 5 & 20,8 & Tuntas & $\geq 70$ & 6 & 100 & Tuntas \\
\hline & $<70$ & 1 & 4,2 & $\begin{array}{l}\text { Belum } \\
\text { Tuntas }\end{array}$ & $<70$ & 0 & 0 & $\begin{array}{l}\text { Belum } \\
\text { Tuntas }\end{array}$ \\
\hline \multirow[b]{2}{*}{ II } & $\geq 70$ & 3 & 12,5 & Tuntas & $\geq 70$ & 6 & 100 & Tuntas \\
\hline & $<70$ & 3 & 12,5 & $\begin{array}{l}\text { Belum } \\
\text { Tuntas }\end{array}$ & $<70$ & 0 & 0 & $\begin{array}{l}\text { Belum } \\
\text { Tuntas }\end{array}$ \\
\hline \multirow[b]{2}{*}{ III } & $\geq 70$ & 4 & 16,7 & Tuntas & $\geq 70$ & 6 & 100 & Tuntas \\
\hline & $<70$ & 2 & 8,3 & $\begin{array}{l}\text { Belum } \\
\text { Tuntas }\end{array}$ & $<70$ & 0 & 0 & $\begin{array}{l}\text { Belum } \\
\text { Tuntas }\end{array}$ \\
\hline
\end{tabular}




\begin{tabular}{|c|c|c|c|c|c|c|c|c|}
\hline \multirow{2}{*}{ IV } & $\geq 70$ & 1 & 4,2 & Tuntas & $\geq 70$ & 6 & 100 & Tuntas \\
\cline { 2 - 9 } & $<70$ & 5 & 20,8 & $\begin{array}{c}\text { Belum } \\
\text { Tuntas }\end{array}$ & $<70$ & 0 & 0 & $\begin{array}{c}\text { Belum } \\
\text { Tuntas }\end{array}$ \\
\hline \multicolumn{2}{|c|}{ Jumlah } & 24 & 100 & \multicolumn{2}{|c|}{ Jumlah } & 24 & 100 & \\
\hline
\end{tabular}

Dari tabel 5. dapat dilihat tes awal mengalami peningkatan jika di bandingkan dengan pertemuan I. Pada kelompok I yang memenuhi kriteria tuntas ada 5 siswa dengan persentase 20,8\% dan 1 siswa lainnya masih belum tuntas kelompok II, ada 3 siswa (12,5\%) memenuhi kriteria, dan 3 siswa $(12,5 \%)$ lainnya masih belum tuntas. Kelompok III, lebih meningkat dari kelompok II, yaitu terdapat 4 orang siswa $(16,7 \%)$ yang memenuhi kriteria ketuntasan dan frekuensi siswa yang tidak memenuhi ketuntasan sebanyak 2 siswa dengan persentase 8,3\% dan untuk kelompok IV hanya 1 siswa $(4,2 \%)$ yang memenuha kriteria tuntas dan sebanyak 5 siswa $(20,8 \%)$ yang belum memenuhi kriteria tuntas.

Untuk tes akhir tampak menunjukan hasil yang sangat baik. Untuk seluruh anggota kelompok I berjumlah 6 siswa (25\%) berhasil memenuhi kriteria ketuntasan. Hal yang sama juga terjadi pada kelompok II dan kelompok III. Pada kelompok hanya 1 orang siswa $(4,2 \%)$ yang tidak memenuhi kriteria ketuntasan, sedangkan 5 siswa $(20,8 \%)$ telah memenuhi kriteria ketuntasan belajar. Dari hasil tes akhir inilah dapat dinyatakan bahwa siswa mampu mencapai ketuntasan dengan total persentase $95,8 \%$ dan hanya 1 siswa (4,8\%) yang tidak memenuhi kriteria ketuntasan tersebut. Perbandingan ketuntasan yang dicapai pada tes awal dan akhir dapat dilihat pada grafik berikut :

Perbandingan hasil tes awal dan tes akhir dapat digambarkan pada grafik 4.

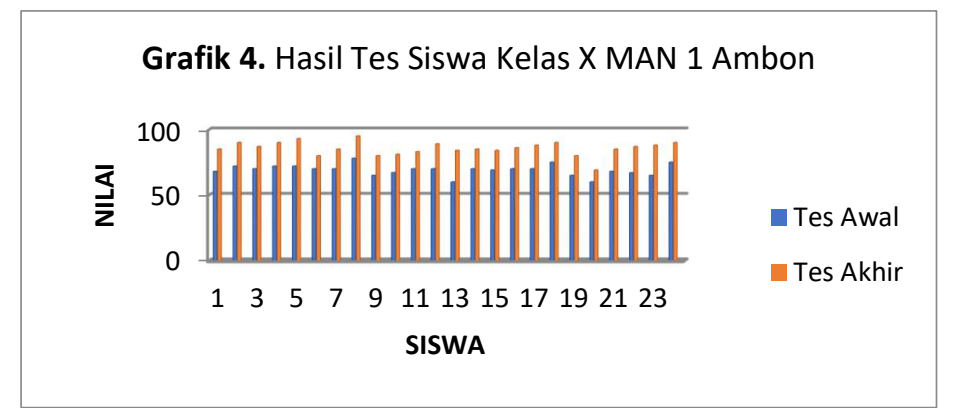

\section{2) Hasil Penilaian Afektif}

Hasil Penilaian Indikator Setiap Kelompok.

Hasil penilaian afektif berdasarkan pengamatan selama pertemuan II untuk masing-masing kelompok dari seluruh indikator adalah sebagai berikut.

Tabel 6. Hasil Penilaian Afektif Siswa Kelas X MAN 1 Ambon

\begin{tabular}{|c|c|c|c|c|c|c|c|c|c|}
\hline \multirow{3}{*}{ Interval } & \multicolumn{8}{|c|}{ Kelompok } & \multirow[t]{3}{*}{ Klasifikasi } \\
\hline & \multicolumn{2}{|r|}{ I } & \multicolumn{2}{|r|}{ II } & \multicolumn{2}{|r|}{ III } & \multicolumn{2}{|r|}{ IV } & \\
\hline & Frek. & $\begin{array}{c}\text { Persentase } \\
(\%)\end{array}$ & Frek. & $\begin{array}{c}\text { Persentase } \\
(\%)\end{array}$ & Frek. & $\begin{array}{c}\text { Persentase } \\
(\%)\end{array}$ & Frek. & $\begin{array}{c}\text { Persentase } \\
(\%)\end{array}$ & \\
\hline $85-100$ & 6 & 25 & 6 & 25 & 5 & 20,8 & 5 & 20,8 & $\begin{array}{c}\text { Sangat } \\
\text { Baik }\end{array}$ \\
\hline $70-84$ & 0 & 0 & 0 & 0 & 1 & 4,2 & 1 & 4,2 & Baik \\
\hline $60-69$ & 0 & 0 & 0 & 0 & 0 & 0 & 0 & 0 & Cukup \\
\hline $40-59$ & 0 & 0 & 0 & 0 & 0 & 0 & 0 & 0 & Kurang \\
\hline$<39$ & 0 & 0 & 0 & 0 & 0 & 0 & 0 & 0 & Tidak Baik \\
\hline
\end{tabular}


Dari tabel 6. di atas menunjukan kelompok I dan kelompok II berada pada klasifikasi nilai sangat baik (interval 85-100) dengan frekuensi sebanyak 6 siswa (25\%). Pada kelompok III dan kelompok IV , 5 orang siswa berada pada klasifikasi nilai sangat baik dengan persentase $20,8 \%$ dan 1 orang siswa $(4,2 \%)$ berada pada interval $70-84$ dengan klasifikasi baik.

Grafik 5. Hasil Penilaian Afektif Seluruh Indikator Pada Siswa Kelas X MAN 1 Ambon

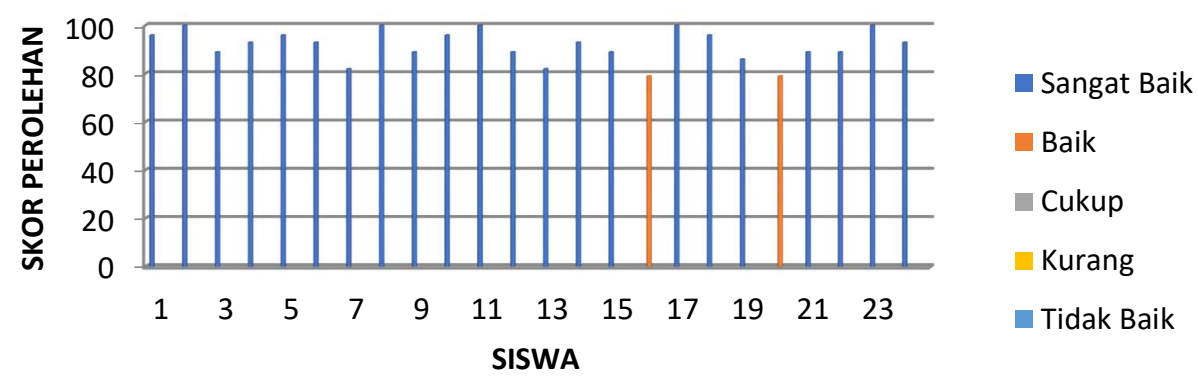

\section{3) Hasil Penilaian Psikomotor}

Hasil Penilaian Seluruh Indikator untuk Setiap Kelompok.

Hasil penilaian psikomotor berdasarkan pengamatan selama pertemuan II oleh masing-masing kelompok dari seluruh indikator adalah sebagai berikut :

Tabel 7. Hasil Penilaian Psikomotor Siswa Kelas X MAN 1 Ambon

\begin{tabular}{|c|c|c|c|c|c|c|c|c|c|}
\hline \multirow{3}{*}{$\begin{array}{c}\text { Inter } \\
\text { val }\end{array}$} & \multicolumn{8}{|c|}{ Kelompok } & \multirow{3}{*}{$\begin{array}{c}\text { Klasifik } \\
\text { asi }\end{array}$} \\
\hline & \multicolumn{2}{|c|}{$\mathrm{I}$} & \multicolumn{2}{|c|}{ II } & \multicolumn{2}{|c|}{ III } & \multicolumn{2}{|c|}{ IV } & \\
\hline & $\begin{array}{c}\text { Frekue } \\
\text { nsi }\end{array}$ & $\begin{array}{c}\text { Persent } \\
\text { ase } \\
(\%)\end{array}$ & $\begin{array}{c}\text { Frekue } \\
\text { nsi }\end{array}$ & $\begin{array}{c}\text { Persent } \\
\text { ase } \\
(\%)\end{array}$ & $\begin{array}{c}\text { Frekue } \\
\text { nsi }\end{array}$ & $\begin{array}{c}\text { Persent } \\
\text { ase } \\
(\%)\end{array}$ & $\begin{array}{c}\text { Frekue } \\
\text { nsi }\end{array}$ & $\begin{array}{c}\text { Persent } \\
\text { ase } \\
(\%)\end{array}$ & \\
\hline $\begin{array}{l}85- \\
100\end{array}$ & 3 & 12,5 & 4 & 16,7 & 2 & 8,3 & 4 & 16,7 & $\begin{array}{c}\text { Sangat } \\
\text { Baik }\end{array}$ \\
\hline $\begin{array}{l}70- \\
84\end{array}$ & 3 & 12,5 & 2 & 8,3 & 4 & 16,7 & 2 & 8,3 & Baik \\
\hline $\begin{array}{c}60- \\
69\end{array}$ & 0 & 0 & 0 & 0 & 0 & 0 & 0 & 0 & Cukup \\
\hline $\begin{array}{c}40- \\
59\end{array}$ & 0 & 0 & 0 & 0 & 0 & 0 & 0 & 0 & Kurang \\
\hline$<39$ & 0 & 0 & 0 & 0 & 0 & 0 & 0 & 0 & $\begin{array}{l}\text { Tidak } \\
\text { Baik }\end{array}$ \\
\hline
\end{tabular}

Tabel 7. di atas menunjukan seluruh indikator penilaian psikomotor pada masing-masing kelompok mengalami peningkatan. Kelompok I yang memiliki klasifikasi nilai sangat baik yaitu pada interval (85-100) sebanyak 3 orang siswa dengan persentase 12,5\% dan 3 orang siswa juga berada pada klasifikasi baik, dengan persentase 12,5\%. Kelompok II dan kelompok IV, masing-masing pada klasifikasi sangat baik (interval 85-100), memiliki frekuensi 4 siswa dengan persentase 16,7\% dan 2 
siswa lainnya berada pada klasifikasi baik (interval 70-84) dengan persentase 8,3\%. Sedangkan untuk kelompok III, 2 orang siswa berada pada klasifikasi baik (interval 85-100) dengan persentase $8,3 \%$ dan 4 siswa lainna berada pada interval (70-84) klasifikasi baik, dengan persentase 16,7\%. Jadi, tidak ada siswa yang berada pada klasifikasi cukup, kurang bdan klasifikasi tidak baik, untuk interval 56-69, 40-55 dan 39 ke bawah.

Grafik 6. Hasil Penilaian Psikomotor Siswa Kelas X MAN 1 Ambon

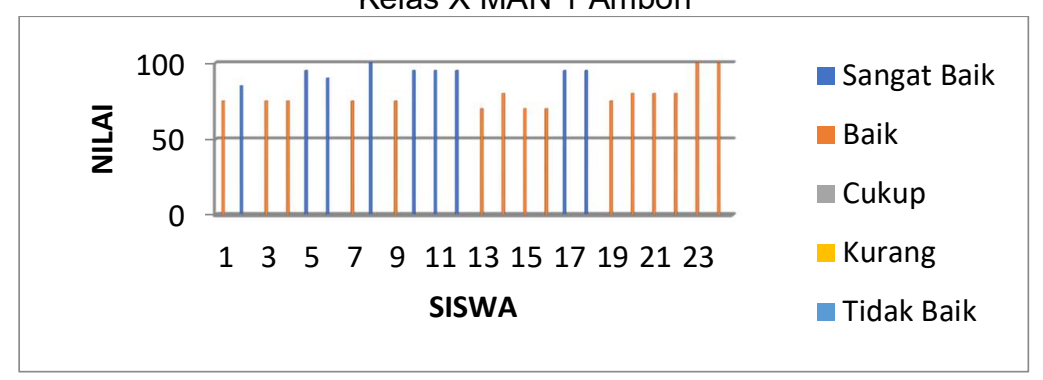

\section{Pembahasan}

\section{1) Penilaian Kognitif}

Dari hasil analisis tes awal, kemampuan awal siswa secara menyeluruh (100\%) untuk memahami konsep struktur atom masih berada dibawah rata-rata, karena tidak memenuhi kriteria ketuntasan minimal (KKM). Siswa dinyatakan tidak memiliki pengetahuan awal dan tidak siap untuk mengikuti pembelajaran. Selama pembelajaran berlangsung, siswa tampak antusias dan bersemangat untuk belajar dan terjadi peningkatan pada tes akhir. Walaupun secara signifikan dan menyeluruh. Pada tes akhir masih terdapat siswa yang belum memenuhi kriteria ketuntasan pada masing-masing kelompok yaitu masing-masing 4 siswa pada kelompok I dan kelompok II, III dan IV masing-masing 3 orang siswa. Dengan demikian jika di rata-ratakan dari keseluruhan siswa total persentasenya adalah $54,2 \%$ yang tidak memenuhi syarat ketuntasan. Jika dibandingkan dengan jumlah siswa yang berhasil mencapai kriteria ketuntasan $(45,8 \%)$ dapat dikatakan belum representatif untuk jumlah siswa sebanyak 24 siswa di kelas VII-4. Karena proses pembelajaran masih jauh dari kriteria ketuntasan. Lebih dari $50 \%$ siswa belum mencapai kriteria ketuntasan hal ini menunjukan bahwa masih banyak siswa yang memerlukan pembimbingan untuk memahami konsep struktur atom secara lebih mendalam.

\section{2) Penilaian Afektif}

Proses penilaian afektif secara menyeluruh pada semua indikator yang dilakukan terhadap siswa dalam kelompok menunjukan adanya variasi skor. Pada tabel 4.2 menunjukan bahwa klasifikasi cukup memiliki persentase tertinggi $(54,1 \%)$. Selanjutnya klasifikasi baik memiliki persentase $(37,5 \%)$ dari klasifikasi nilai kurang. Klasifikasi nilai tidak baik berada pada urutan terakhir dengan persentase terendah yaitu $8,4 \%$. Sedangkan pada masing-masing kelompok yang mendominasi klasifikasi baik adalah kelompok II dan kelompok IV (12,5\%) dan menyusul kelompok III dengan persentase $8,3 \%$ dan kelompok I berada pada bagian terakhir, yaitu klasifikasi $4,2 \%$.

\section{3) Penilaian Psikomotor}

Kecakapan psikomotor adalah unjuk kerja yang nyata dan mudah diamati baik kuantitasnya maupun kualitaasnya karna sifatnya terbuka. Namun disamping kecakapan psikomotor itu tidak terlepas dari kecakapan kognitif dan juga banyak terkait oleh kecakapan afektif. Jadi kecakapan psikomotor siswa merupakan manifestasi wawasan pengetahuan dan kesadaran sikap mentalnya (Syah. M,2003).

Saat proses belajar mengajar berlangsung tampak adanya kolaborasi antara guru dengan siswa melalui model pembelajaran langsung, siswa pada masing-masing kelompok tampak dengan lantang menunjukan setiap indikator pada penilaian psikomotor tanpa direkayasa meskipun ada 
sebagian besar siswa yang tidak mencapai rata-rata. Sama seperti pada ranah afektif, kondisi siswa yang heterogen dan saling mempengaruhi akhirnya terlihat pada setiap indikator yang dinilai.

\section{KESIMPULAN}

Berdasarkan hasil penelitian dapat disimpulkan bahwa penerapan model pembelajaran langsung (direct learning) dapat meningkatkan hasil belajar konsep struktur atom pada siswa kelas $X$ MAN 1 Ambon yang ditunjukan dengan meningkatnya hasil belajar siswa melalui nilai pada aspek kognitif, afektif, psikomotor, dan nilai akhir.

\section{DAFTAR PUSTAKA}

Arikunto, S. (2006). Prosedur Penelitian Suatu pendekatan Praktik Edisi Revisi VI. Jakarta : Rineka Cipta.

Michael Purba. 2006. Kimia Untuk Kelas X. Jakarta: Erlangga.

Sardiman, A.M. (2011). Interaksi dan Motivasi Belajar-Mengajar. Jakarta: PT Rajagrafindo Persada Syah, Muhibbin. 2000. Psikologi Pendidikan. Bandung: Remaja Rosdakarya.

Sudijono, A. (2009) . Pengantar Evaluasi Pendidikan. Jakarta: Rajawali Pers, 69-70x.

Wenno. I. H. 2008. Strategi Belajar Mengajar Sains Berbasis Kontekstual. Inti Media : Jogjakarta 